\title{
Blogging in China: Freedom of Expression vs Political Censorship in Sexual and Satirical Blogs
}

HAI TANG, University of Sussex

\begin{abstract}
The growing use of the web log reveals a radical socio-cultural transition and a progressing public sphere in China. In particular, bloggers actively exchange interests, comments and values and have formed a characteristically Chinese blogging culture. The feature of individualism shows that bloggers who insist on freedom of expression and pursue personal ideas can always find a place in the blogosphere. The two examples given in this paper - Muzimei's sexual diary and Wang Xiaofeng's satirical blog - demonstrate that individual opinions across the blogosphere have significantly reflected public consensus and implicitly changed political culture. However, the pursuit of freedom of expression in the blogosphere has to struggle with a strong political censorship, negotiate an unstable living space and thus, can only enjoy a limited success. Therefore, critical communication and democratic participation in China still have a long way to go.
\end{abstract}

\section{KEYWORDS}

Public Sphere; Chinese Blogosphere; Freedom of Expression; Political Censorship.

\section{Introduction}

Marked by new forms of interactive communication, the growing use of the web log by active bloggers, whether in field of mainstream politics, culture or society, has been taken as the evidence of a new public sphere in China. By "newness" I mean, firstly, its Chinese character; secondly, the continuities and differences between old and new communication systems; and thirdly, radical changes in communication. In this sense, the Chinese blogosphere, as a public sphere, represents the very differences that come with the Habermasian public sphere. Habermas's notion of the public sphere requires a degree of autonomy for public opinions to directly impact on politics (Rankin, 1993, p.159). As an alternative, the Chinese blogosphere shows an ongoing socio-cultural transition alongside the dominant political culture. It provides for a dual-way 
interaction (Chen, 1991; Lax, 2000) in addition to the communicative action and especially, an emerging individual 'discursive practice' (Hall, 1997, p.222) that reflects public interest and further matters to public opinion in the public sphere.

How is this new public sphere proceeding in the development of interactive communication? How is the blog reshaping the form of political culture? This paper focuses on these questions, with the purpose of describing, analysing and exploring the Chinese blogging culture. As Philip Huang states, the public sphere can create a space in between state and society that will bring changes by affecting both (1993, p.222). At this point, the Chinese blogosphere arguably refers to an online space of intermediate structures between the individual and state. The exchange of opinion, expression and criticism by individuals across the blogosphere has posed potential challenges in terms of mediating relationships and creating new bonds among individuals, state and society as well as the political implications that ensue (Klinenberg and Benzecry, 2005).

However, the Western account of the public sphere originally appears to denote a mass welfare state inseparable from a liberal civil society (Habermas, 1989). To put it another way, the public sphere links between liberal models of political structure and the ideal-type of civil society exists within a particular Western historical setting. But neither concept fits with China's political culture because, from the liberal perspective, China has too much state control and especially lacks a progressive civil society (Gupta, 1995, p.309). For example, the students' protest movement in 1989, starting with the Beijing Spring "Street Theatre" (Esherick and Wasserstrom, 1994, p.43) for political democracy, ultimately led to the Tiananmen Square Massacre, attributable to the absence of civil society and political public sphere (Wakeman and JR, 1993). Identically, freedom of speech is always in conflict with political censorship and can only enjoy a narrower degree of autonomy in the Chinese blogosphere. Two examples are particularly illustrated to develop this case in the paper: Muzimei and her Yiqingshu (Love Letters Left), and Wang Xiaofeng's Buxulianxiang (No Imagination).

\section{The Line of Authority}

As one of the prominent components in the socialist society under the leadership of the Chinese Communist Party, ownership and control of the media are internal and intrinsic forms of political power in China (Zhang, 1997, p.126). Here, the political power, in James Lull's idea, is closely related to social rules (2000, p.92). For example, a president can impose military power on his ruled people, or the company's CEO (chief executive officer) can be respected because of his particular social status.

Historically, Chinese political elites have manipulated the media to be an instrument of ideological propaganda over the masses. Thus, the mass media in China commonly struggles with explicit rules and a bureaucratic system (Winfield \& Peng, 2005, p.257-8). Indeed, the development of Internet in China, as a communicational channel 
and a type of technological tool, is inseparable from this sociopolitical context in terms of its orientation and diffusion (Tsui, 2005; Zhang, 2006). For instance, the state has categorised prohibited online content, messages and publishing based on five key points: (1) information that goes against the basic principles set down in the Constitution; (2) information that endangers national security, divulges state secrets, subverts the government, or undermines national unification; (3) information that is detrimental to the honour and interests of the state; (4) information that disseminates rumours, disturbs social order, or undermines social stability; and (5) other generally 'harmful' and criminal information that is prohibited by the law or administrative regulations (CNNIC, 2005).

The above criteria clearly reveal a proactive control of online activities via the legislative political censorship. It means that Chinese government leaders control public communication in respects to the information producer (informant) and media production (content), which, as they perceive it, could become a great threat to the political authority (Lu and Weber, 2007, p.927).

There has been evidence of a certain degree of friction between the Chinese leadership and those popular blog sites. Recently, the Chinese government has soliciting public opinions about its draft "Blog Service Self-discipline Public Pledge". The draft calls for BSPs (blog service providers) and bloggers to enter into a service agreement, including a guarantee that they will not distribute pornographic stories or anything derogatory to ethnic and cultural traditions. In addition, bloggers will have to manage and supervise their comments on their blogs, especially removing 'illegal' comments as soon as possible (Cited in Alexandri, 2007). By the same token, the draft also requires all bloggers to register their real name, where bloggers have to provide their full names with an identifying number such as national ID number, military officer number or passport number and contact information, including a phone number or an email address, though the agreement claimed that bloggers can still remain anonymous on screen, and their real names are only disclosed to the BSPs.

Chinese Internet Society Industry Self-Discipline Committee secretary-general Yang Junzuo (Cited in Zhao, 2006) offered three reasons for these measures, and emphasised the importance of this real name registration system: firstly, the Real-Name Blogger Registration System will lessen the chances of personal attacks (for instance, fraud, libel and similar problems); secondly, if these kinds of problem were to happen, the Real Name System can quickly trace and then find the identities and ultimately 'resolve' the problem; thirdly, the rule would be beneficial for building a harmonious Internet ecology and puts less pressure on those BSPs.

But Chinese bloggers have vigorously resisted the Real Name Registration policy. For example, take Wang Xiaofeng, who says in his blog Buxulianxiang (No Imagination):

It is said that there are some possibilities of libel, fraud and slandering in the blogosphere. As a consequence, a certain official department has decided to 
implement the Real Name Registration policy. In so doing, we bloggers will be 'protected' and there seems nothing we should worry about...But I am afraid there is some ulterior motive. (24 October 2006)

Not only bloggers, but also some popular blog sites such as Bokee.com say directly that they are against any Real Name Registration policy. President Fang Xingdong (cited in Zhao, 2006) says the Real Name Registration System would be the biggest joke as it violated people's basic rights, and will negatively force bloggers to choose overseas blog service providers instead of domestic ones.

Tech-blogger Hong Bo makes a mutual concession,

The original structure of the Internet was not designed for the ruling elites but for ordinary netizens to search for information. In my opinion, the Real Name Registration, up to a certain degree, may promote dual interaction between celebrities and their fans. This is good. But the current policy will necessarily intrude on people's privacy or limit their access. This is bad. (25 January 2008)

It is clear then that the Real Name Registration System seems to be unacceptable and unpleasant to Chinese bloggers. The disadvantages are, of course, that bases of open politics and citizenship rights are not very supportive in society (Esherick and Wasserstrom, 1994). To be sure, Chinese people expect the Internet to bring more freedom of speech and more political opportunities. For example, a survey conducted in October 2003 by the Chinese Academy of Social Sciences found that Internet development in China has attracted wide attention from media reporters, academic researchers, and radical politicians, many of whom are fueled by the hope that the new media would fundamentally lead to a more democratic and open Chinese political system (Guo, 2003, p.13).

\section{The Rise of Blogs}

There are, of course, strong weaknesses in the political system of China - in terms of historical evidence and limits or omissions in the process of socialist transformation. However, one should acknowledge the real dynamics of change in Chinese society from past to present, and focus on the inclusion of these achievements (Mohanty, 1990; $\mathrm{Gu}$, 1993). China's long-term economic reform, for instance, has been gradually weakening direct state control on social and economic life (Ding, 1998). Added to this is the pervasive spread of commercial media and new media outside the sphere of direct political control (Ma, 2000, p.26).

China is increasingly becoming one of the most networked nations in the world, and it has long been considered as having a highly networked form of social organisation. The 
official China Network Information Centre (CNNIC) report estimated the number of 'Chinese netizens in early 2004 at 87 million. This is up from 26 million in 2001, indicating a tripling of Internet users in just three years'; meanwhile, China had nearly 31 million computer hosts and the number of domain names with .cn grew massively on what it was 10 years ago (Lu, Du, et al., 2002, p.222; Kluver, 2005, p.30). With the modern network system now allowing interactive connectivity, it is well documented that the capacity for participatory communication such as online newspapers and discussion forums is greater than ever before. On the one hand, it is influenced by the active media practitioners and audiences, and their urgent need for interactive communication. On the other hand, varied online communication channels are personified as the diffusion of cultural values and innovations of a society (He and Zhu, 2002, p.122). As John Thompson (1990, p.115) puts it:

The development of mass media has created new opportunities for the production and diffusion of images and messages, opportunities which exist on a scale and are executed in a manner that precludes any serious comparison with the theatrical practices of feudal courts.

Taking the web log, for example, Chinese people's access to blogs grows exponentially every year. According to Baidu, China's biggest search-engine website, bloggers and web log sites reached 16 million and nearly 37 million respectively by the end of 2005 (He, 2005). As a communication space, it has empowered Chinese netizens to actively post radical views and opinions for conversation. The impact of the blog, to some extent, is not only direct but also unavoidable, because the flow of various contents across China's blogosphere are prominent, and these contents have offered Chinese bloggers more resources for constructing arguments and criticisms towards a transformation of ethical and political cultures. This interactive shift suggests additionally that the online communication of many-to-many messages that bypasses the public sphere (Castells 2008, p.80) would possibly institute a dialogue between political elites and the public. Yang Guobin and Craig Calhoun say: 'Communications and debates in the public sphere channeled citizen opinions to influence government policies' (2007, p.212). Even more significantly, the Western conception of the emphasis on free and competent communication with individual and personal rightness (Golding, 1995; Habermas and Rehg, 1998) has proved particularly attractive to Chinese bloggers. Chinese domestic bloggers are increasingly using their spaces to call for a voice in the process around which they can build a consensus in a struggle with the government for political participation (Wall, 2003). The mass expression of radical opinions would in effect, play a role in pressurising the government.

\section{Muzimei's 'Yiqingshu' (Love Letters Left)}

It is as part of this process that the blog is potentially organising public debate on various topics as well as suppressed and sensitive social issues (McGuigan, 1996, p.27), whether the public is aware of it or not. As Nancy Fraser (1997) argues, the public 
sphere is not only there to identify the space in which citizens deliberate about their personal concerns through communication activity, but also to designate their discursive practices as an affective realm as public opinion. In the Chinese blogosphere, discussions on women's affairs - the implicit and private events and in particular, sexual life - have become one of the standard radical themes among Chinese bloggers.

Although the term 'blog' was introduced to Chinese culture by regular web surfers in China, particular attention was drawn to it by a magazine writer in Guangzhou in Southern China, who wrote under the name Muzimei. Muzimei began to write a sex diary on Blogen.com in 2003: 'I have a job that keeps me busy, and in my spare time I have a very humanistic hobby - making love' (Love Letters Left, cited in Bonobo Land, 28/11/2003). Muzimei has created her own desired lifestyle through her blog, and sex, which motivates her blog, has become the unique theme of her writing. She documents her sexual experience and posts her views in her blog, Yiqingshu:

The partner I take in my hobby is one I choose and always changes. I rely on a large supply pool. I do not need to take any responsibility for them; neither should I give them love. They will not cause me problems. They are like CDs, which will not make a sound unless I play them. (Love Letters Left, cited in Bonobo Land, 28 November 2003).

To be sure, the Muzimei phenomenon is a hit in Chinese society. China's biggest Internet site, Sina.com (Cited in Zhou, 2003), credits her with attracting 10 million daily visitors. Another popular site, Sohu.com (Cited in Xinkuaibao, 2003), says Muzimei is the most frequently typed name into its Internet search engine. Some people may have been shocked by her direct views on sex but others admired her because she sees sex as a personal basic right which should be faced up to in modern society. This is not to say that everyone that engages in the blogosphere should have been interested only in sexual interaction. There is, however, a more positive way of respecting and allowing for not only physical presentation, but also a certain freedom of self-expression beyond one's real-life limitations (McRae, 1997) in the cyberspace.

Muzimei's blog has ignited a major nationwide debate over Chinese moral tradition. Historically, Chinese people were sexually restrained. Chinese culture has frequently found the enormous range of personal emotions and sexual experiences to be neither expressible in language, nor are they possibly permitted and brought to attention and discussed in the open. The inherent Confucian ethical system has educated the Chinese people to respect and value chastity and keep away from 'evil' and 'dishonour'. For example, a woman's personal experiences of sexual life have been hitherto considered too shameful and could harm familial and societal stability (Evans, 1997). An exaggerated interest in sexual matters is deemed wrong and unacceptable because it may detract from Chinese moral education (Evans, 1997, p.75). Furthermore, the pervasive Western idea of sexual liberation and its allegedly negative effects on the 
juvenile crime rate suggest that the supervision and control of explicit sexual topics is necessary and important to the Party-state authorities (Anderson and Gil, 1998). In other words, political mechanisms such as official rules and laws still play a major role in social control. However, sexual liberation, accompanied with the slogan of 'No More Nice Girls' (De Kloet, 2008, p.195), up to a point, is following the process of encouraging the people of China to break out of the orthodox Confucian morality towards a new culture.

It is possible to argue that traditional Chinese ethical values have struggled in the onslaught brought on by new means of communication. The rise of the blogosphere is providing more spaces for freedom and rights, and developing an open and progressive public sphere. In the case of Muzimei, located within a basic right of sexual equality, she rediscovered a private space for intimate depiction and a public space for the extending the range of resistance to traditional thought (Ping, 2005). The example of Muzimei's story dramatically illustrates that sexual feelings represent an individual rebellion against official ethical values, and symbolise a touchstone in the struggle for personal freedom (Barnett, 2004, p.60). As Muzimei said in an interview: 'I think I am not just talking about my life and my stories in my blog. I mean, the sex part...I am more interested in what the sex topic would bring in terms of expanding discussion and exploration in society. In this sense, I feel like I am providing a space of power for the right to speak" (Cited in Xiao, 2004).

\section{Wang Xiaofeng's 'Buxulianxiang' (No Imagination)}

Paul Manning (2001) notes that there might be entertainment value inside communication. On one level, political topics are of vital importance, but may seem distant from the daily practice of communication. Following such a relativistic position, people who are meant to benefit from the political culture have already grasped more popular forms (Stevenson, 1995, p.57). This produces another radical theme of the Chinese blogging culture, for which I will borrow Brian McNair's term - 'the satirical column' (2000, p.67). Wang Xiaofeng, who names his blog 'Buxulianxiang' (No Imagination) (http://www.wangxiaofeng.net), provides a distinctive model of political satire among Chinese blogs. In his E Gao (Satire), Wang says:

It is not allowed to tease the leaders in our country. I remembered that someone composed a song mocking the county leader and resulted in being arrested. As a consequence, the Chinese 'envy' the Americans because their presidents would constantly be the object of much satire... China has a long history of 'respecting' the top-authoritative power since the Qing dynasty because those ancient emperors likely constructed special regulations to torture people. After rebuilding the new China, people preferred to celebrate a none-emperor nation whereas Mao appeared to be a new emperor in Modern China. During the Cultural Revolution period, Mao brought about many taboos. (16 January 2008) 
Wang continues,

For instance, a newspaper editor had to carefully place the 'Chairman Mao', 'Mao Zedong' and 'Long Life Chairman Mao' into one paragraph, otherwise he would be suspected as a counter-revolutionary and punished miserably...We should say that the 'ability to talk', in terms of politics, merely has a restricted space in China. (16 January 2008)

Wang then exemplifies,

Recently, Citroen produced an advertisement making fun of Mao that led to a national protest against the company, and Citroen had to later apologise to the Chinese government. The Westerners, they 'deserved' to be 'resisted' because they don't know that Great Chairman Mao should not be teased in China. (16 January 2008)
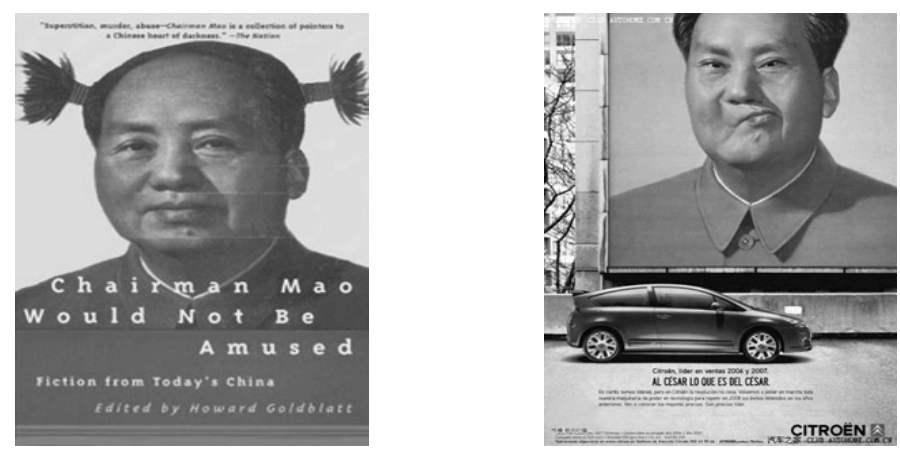

From his writing, we can see that Wang Xiaofeng's language is founded on the liberal use of satire, irony and humour, with a disrespectful attitude. This is attractive to his readers. According to Minabere Ibemema, the nation's political dimension usually influence the ways people judge values and post comments in matters of governance (2001, p.18). But there is also, from the experience of social practice in China, a strong tradition of critical communication and political expression expressed through sneering and subversive points of view. Historically, satirical columns have been attractive as indeed have the ancient 'Minyao' (folk sayings), 'Shunkouliu' (rhyming sayings) and 'Yanyu' (popular sayings) in China. For example, 'Shunkouliu' was a popular sign of criticism of the political system during the Cultural Revolution, a common symptom of dissatisfaction with political reform by the late 1980s and a signal reflecting mass opinions in contemporary Chinese society (Barme, 1993, p.2). By the same token, the Chinese blog's satirical column stands for the perception of fighting with 'setting limits' (Williams, 1991, p.408) on issues of freedom of speech. 
The freer discussions that take place on blog spaces potentially serve to foster a new wave of columnists (Poster, 2001, p.4). Indeed, Chinese satirical bloggers are quite familiar with the rules of the 'party line' (Winfield and Peng, 2005, p.256). For example, they will carefully select politicians and affairs to comment on. In the case of Wang Xiaofeng, he laughs at the previous president, and this attitude does little to threaten the current Party leaders. Wang enjoys his clever usage of satirical language, and he aims particularly at playing up to the authoritative political system. Yet, it would appear to be a kind of mild form of dissent which the political authorities are able to accommodate. As Gregor Benton points out,

...the more cynical and far-sighted among them know that political jokes and the other small freedoms that irritate some zealots are a useful means of dissipating tensions and of keeping people happy... To permit the jokes against the state is... a clever insurance against more serious challenges to the system. (1988, p.41)

In addition, a satirist blogger to some extent plays 'the role of social critic' and 'speak[s] for society', to borrow from James Curran (2002, p.98). The purpose of satirical blogs is to make the political open and public (Esherick and Wassertrom, 1994, p.51). A direct consequence for Internet sites is that they can attract maximum audiences. The popularity of Wang's Buxulianxiang has created a new model of political expression and illustrates a demand for a more open political process (Esherick and Wasserstrom, 1994, p.56; Chan, et al. 2006, p.928-929) via various voices engaged in the blogosphere.

Furthermore, satirical critics predict that the rise of online communication will translate into a competition against press media for producing political comments. The blogosphere has demonstrated that it has the power to penetrate into the heart of society, either by breaking official news or by organising public debates. Both elements have become an essential part of the blog's dynamic nature. However, as Bill Nichols argues,

The cybernetic metaphor invites the testing of the purpose and logic of any given system against the goals of the larger ecosystem where the unit of survival is the adaptive organism-in-relation-to-its environment, not the nomadic individual or any other part construing itself as autonomous or "whole". (2000, p.112)

In this situation, the explosion in commentary in the blogosphere is an intelligible adaptation to an environment which is intensively manipulated by China's political elites (Perry, 1994, p.3). We hope that the growing market-economic policy will continue to force the administrative boundaries to provide a larger online space for political participation (Chan, 2003, p.171-4). 


\section{Conclusion}

Chinese bloggers represent a will to be identified as individuals. On the one hand, bloggers are willing to show 'pleasure, autonomy and a sense of self' via their blogs (Stevenson, 1995, p.57). The growing popularity of sensitive sexual blogs and satire of politicians imply that bloggers who insist on freedom of speech and pursue personal ideas can find a place in the blogosphere. In addition, blogs have been marked by 'the increasing usage of popular culture' (Ma, 2000, p.28), with the aim, as Nick Stevenson says, 'through exaggeration and excess, to question the normal and the official' (1995, p.58). On the other hand, as Jean Seaton argues,

just as little 'serious' material is presented without a sugar coating, so too there is nothing - or almost nothing - that can be deemed 'pure' entertainment. Soap opera, comedy, variety, and pop may not be intended to have any effect on the views of their audiences. But, it can be argued, there is scarcely a joke or a lyric that does not reflect a social attitude, and one with political consequences. (1991, p.266)

Seaton's opinion means as well that popular culture, in aspects of entertainment and leisure areas, to some extent refers to the details of political practice (Scott and Street, 2001; Fung, 2003). This in turn suggests that blogs, to the extent that they invite personal expression in the political process (Klinenberg and Benzecry, 2005, p.11), form a public sphere to negotiate with political domination, gently pushing the state to allow more social spaces to flourish.

Secondly, the new media and the Internet-based communication, as John Thompson points out (1995, p.245), can create a new type of value in the public sphere and potentially offer more in-depth political debate than ever before. The purpose of a participatory media for open and critical speech has inevitably coincided with the nation's active blogosphere. The blog radically differs from regular Chinese mass media in aspects of its interactive, borderless and personalised communication. The decentralised mode of network structure has resulted in a relatively more fluid and malleable public sphere than traditional media such as newspaper and broadcasting can deliver. As participatory media, blogs have vast advantages in providing alternative information, and their unorthodox sources such as transnational affairs, intriguing stories and anecdotes seem to have offered freer spaces in the realms of culture and society (Zheng and Wu, 2005, p.515). However, as Muzimei comments, 'Blogging in China is more apolitical rather than political. Bloggers can either talk about president-election and political democracy, or criticise Bush, Blair and Putin for the World's ills in Western society; however, all these will be taken down in China. Therefore, the Chinese characteristic of "forbidden" culture stimulates an "allegorical" 
blogging culture' (Cited in DW-WORLD, 3/11/2004). Perhaps the proliferating freedoms in terms of individual expression and personal conscience mean that a more liberal public sphere might be expected and taken for granted in future.

Last but not least, the term public opinion, according to Habermas, 'refers to the functions of criticism' (1991, p.399), and the influx of private interests will win 'priviledged representation' (1991, p.403) within the public sphere. The expanded blog space mentioned above can be described as a zone of freedom of expression which confronts the state as a domain of private autonomy. In the context of the individual blogs analysed in this paper, their move from implicit statements of 'special interests' (sexuality or irony) towards a broader populist sense of public power (Calhoun, 1994, p.105) certainly remained their critical functions. However, this kind of 'privileged representation' is restricted to apolitical and consumerist contents (Ma, 2002, p.308), also excluded from democratic expression. As Colin Sparks puts it,

Democracy, in the modern sense of the word, is literally impossible without the media. It is a characteristic claim of Western societies that they are democractic precisely because they have both regular elections and a free media. One of the charges brought against the countries of Eastern and Central Europe was that, whatever they claimed about themselves, they were not democratic because these two conditions were absent. (1998, pp.16-17)

Sparks's opinion mentions that a weak media system can offer few opportunities to create a genuine political public space. For this reason, the practice of liberal and democratic reforms has therefore been seen as politically difficult in China (Calhoun, 1994; Esherick and Wasserstrom, 1994; Gupta, 1995). Elizabeth Perry notes that China's weak civil society has reduced its fervour for political change (1994, p.7). The example of the Real Name Registration policy forces Internet sites to compromise with official state policy. For security purposes, these popular sites have had to negotiate their living space (Xin, 2002) rather than make any fundamental change. However, Scott Lash (2002, p.35) argues that it is only politics with common recognition that can satisfy the public, and this is achieved when it takes place both in nation-state and the public sphere. Therefore, it seems a better suggestion that the people of China first call for a 'civil government' (Gupta, 1995, p.313), which is a more realistic, urgent and significant prospect than a civil society.

\section{References}

Anderson, A. F and Gil, V. E. (1998) China's Modernization and the Decline of Communitarianism: the Control of Sex Crimes and Implications for the Fate of Informal Social Control. Journal of Contemporary Criminal Justice Vol.14 (3), pp. $248-261$. 
Alexandri, M. (26 May 2007) The Bloggers' Self Discipline Pledge [online]. Available from http://www.danwei.org/blogs/what_do_you_think_of_selfdisci.php [accessed 28 June 2008].

Barme, G. (1993) Culture at Large: Consuming T-Shirts in Beijing. China Information Vol. 8(12), pp.1-41.

Barnett, C. (2004) Neither Poison nor Cure: Space, Scale and Public Life in Media Theory. In Nick C. and Anna M., eds. Mediaspace: Place, Scale and Culture in a Media Age. London: Routledge, pp.58-74.

Benton, G. (1988) The Origins of the Political Joke. In Chris P. and George. E. C. P. eds. Humour in Society: Resistance and Control. London: Macmillan. pp. 33-55.

Bonobo Land (28 November 2003) The Muzimei Phenomenon and its Impact on the Chinese Internet [online]. Available from:

http://bonoboathome.blogspot.com/2003/11/muzimei-phenomenon-and-its-impact-on. html [accessed 28 June 2008].

Brewer, P. R. (2006) National Interests Frames and Public Opinion about World Affairs. The Harvard International Journal of Press/Politics Vol. 11(4), pp. 89-102.

Calhoun, C. (1994) Science, Democracy, and the Politics of Identity. In Jeffrey, N. W. and Elizabeth, J. P., eds. Popular Protest and Political Culture in Modern China. Westview Press, pp. 93-124.

Castells, M. (1997) The Power of Identity. Blackwell.

Castells, M. (2008) The New Public Sphere: Global Civil Society, Communication Networks and Global Governance. The ANNALS of the American Academy of Political and Social Science Vol. 616 (1), pp. 78-93.

Chamberlain, H. B. (1993) On the Search on Civil Society in China. Modern China Vol. 19 (2), pp.199-215.

Chan, J. M. (2003) Administrative Boundaries and Media Marketization: A Comparative Analysis of the Newspaper, TV and Internet Markets in China. In Chin-Chuan L., ed. Chinese Media, Global Contexts. London: Routledge, pp.159-176.

Chan J. M., Lee, F. L. F. and Pang, Z. D. (2006) Online News Meets Established Journalism: How China's Journalists Evaluate the Credibility of News Websites. New Media \& Society Vol. 8 (6), pp: 925-947.

Chen, L. (1991) Culture, Politics, Communication and Development - A Tentative Study on the Case of China. International Communication Gazette Vol. 48 (1), pp. $1-16$.

CNNIC (8 June 2005) Internet Laws and Regulations [online]. Available from: http://www.cnnic.cn/index/0F/index.htm [accessed 28 June 2008]. 
Curran, J. (2002) Newspapers: The Sociology of the Press. In Adam B and Paul C., eds. The Media: An Introduction. London: Person Education, pp.89-102.

De Kloet, J. (2008) Gendering China Studies: Peripheral Perspectives, Central Questions. China Information Vol. 22 (2), pp. 195-219.

Ding, Y. J. (1998) Corporatism and Civil Society in China: An Overview of the Debate in Recently Years. China Information Vol. 12(4), pp. 44-67.

Esherick, J. W. and Wasserstrom J. N. (1994) Acting out Democracy: Political Theater in Modern China. In Jerry N. W and Elizabeth J. P., eds. Popular Protest and Political Culture in Modern China. Westview Press, pp. 32-70.

Evans, H. (1997) Woman and Sexuality in China: Dominant Discourses of Female Sexuality and Gender Since 1949. Polity Press.

Fraser, N. (1997) Justice Interruptus: Critical Reflections on the "Postsocialist" Condition. London: Routledge.

Flew, T. (2004) New Media: An Introduction. Oxford University Press.

Fung, A. (2003) Marketing Popular Culture in China: Andy Lau as a Pan-Chinese Icon. In Chin-Chuan L., ed. Chinese Media, Global Contexts. London: Routledge-Curzon, pp.257-269.

Golding, P. (1995) The Mass Media and the Public Sphere: The Crisis of Information in the 'Information Society', In Stephen E., Sandra W. and Gareth W., eds. Debating the Future of the Public Sphere: Transforming the Public and Private Domains in Free Market Societies. Avebury, pp.25-40.

Gu, X. (1993) Review Article: A Civil Society and Public Sphere in Post-Mao China? A Overview of Western Publications. China Information Vol. 8 (3), pp. 38-52.

Guo, L. (2003) Survey Internet and Impact in Twelve Cities [online]. Research Center for Social Development of the Chinese Academy of Social Sciences. Available from: http://www.markle.org/downloadable_assets/chinainternet_usage.pdf [accessed 28 June 2008].

Gupta, K. P. (1995) Models of Governance and the Range of Social Space: A Second Look at the State and Civil Society Debate in China and India. China Report Vol. 31(3), pp. 307-329.

Habermas, J. (1989) The Structural Transformation of the Public Sphere: An Inquiry into a Category of Bourgeois Society. Polity Press.

Habermas, J. (1991) The Public Sphere. In Chandra M. and Michael S., eds. Rethinking Popular Culture: Contemporary Perspective in Cultural Studies. University of California Press, pp. 398-404.

Harbermas, J and Rehg, W. (1998) Remarks on Legitimation through Human Rights. 
Philosophy \& Social Criticism Vol. 24 (23), pp. 157-171.

Hall, S. (1997) The Centrality of Culture: Notes on the Cultural Revolutions of Our Time. In Kenneth T. ed. Media and Cultural Regulation. Open University, pp. 208-238.

He, W. H. (20 December 2005) Baidu Pilu Zhongguo Boke Shuju (Baidu: How Many Bloggers in China) [online]. Available from:

http://tech.qq.com/a/20051220/000016.htm [accessed 28 June 2008].

He, Z. and Zhu, J. H. (2002) The Ecology of Online Newspapers: the Case of China. Media, Culture \& Society Vol. 24 (1), pp. 121-137.

Hong, B. (25 February 2008) Quan Mian Shi Xing Shimingzhi bu Xianshi (The Implement of the Real Name Registration is Unrealistic in China) [online]. Available from:

http://news.sina.com.tw/tech/sinacn/cn/2008-02-25/125538230816.shtml [accessed 28 June 2008].

Huang, P. C. C. (1993) "Public Sphere"/"Civil Society" in China: The Third Realm between State and Society. Modern China Vol. 9 (2), pp. 216-240.

Ibemema, M. (2001) Perspectives on Mass Communication and Cultural Domination. In Humphrey A. R., ed. Culture and Mass Communication in the Caribbean. University Press of Florida, pp.15-36.

Klinenberg, E. and Benzecry, C. (2005) Introduction: Cultural Production in a Digital Age. In Erik K., ed. Cultural Production in a Digital Age. London: Sage, pp.6-18.

Kluver, R. (2005) US and Chinese Policy Expectations of the Internet. China Information Vol. 19 (2), pp. 299-324.

Lash. S. (2002) Critique of Information. London: Sage.

Lax, S. (2000) The Internet and Democracy. In David G., ed. Web. Studies: Rewiring Media Studies for the Digital Age. Arnold, pp.159-169.

Lu, J. and Weber, L. (2007) State, Power and Mobile Communication: A Case Study of China. New Media \& Society Vol. 9 (6), pp. 925-944.

Lu, W., Du, J., Zhang J., Ma F. C. and Le T. W. (2002) Internet Development in China. Journal of Information Science Vol. 28(3), pp. 207-223.

Lull, J. (2000) Media, Communication, Culture: A Global Approach. Polity Press.

Ma, E. K-W. (2000) Rethinking Media Studies: The Case of China. In James C. and Myung J. P., eds. De-Westernizing Media Studies. London and New York: Routledge, pp. 21-34.

Ma, Q. S. (2002) The Governance of GNOs in China Since 1978: How Much Autonomy? Nonprofit and Voluntary Sector Quarterly Vol. 31(3), pp. 305-328 [online]. 
Manning, P. (2001) News and News Sources: A Critical Introduction. London: Sage.

McGuigan, J. (1996) Culture and the Public Sphere. London: Routledge.

McNair, B. (2000) Journalism and Democracy: An Evaluation of the Political Public Sphere. London: Routledge.

McRae, S. (1997) Flesh Made Word: Sex, Text and the Virtual Body. In David, P. ed. Internet Culture. London: Routledge, pp.73-86.

Mohanty, M. (1990) The Political Economy of the Development in China: Socialism in the Freedom Scale. China Report Vol. 26 (1), pp. 33-45.

Muzimei (3 December 2004) Boke Ziyou yu Zhongguo Tese (Free Blogging and Chinese Characteristics) [online]. Available from:

http://www.dw-world.de/dw/article/0,2144,1417327,00.html [accessed 19 November 2008].

Myers, G. (2004) Matters of Opinion: Talking about Public Issues. Cambridge University Press.

Nichols, B. (2000) The Work of Culture in the Age of Cybernetic Systems. In John T. C., ed. Theories of the New Media: A Historical Perspective. London: Athlone Press, pp. 90-115.

Perry. E. J. (1994) Introduction: Chinese Political Culture Revisited. In Jeffrey N. W. and Elizabeth P., eds. Popular Protest and Political Culture in Modern China. Westview Press, pp. 1-14.

Ping, W. (2005) Nu Shu: Female Writing in China. In Constance C., ed. The Book of Touch. Oxford: Berg, pp.220-227.

Poster, M. (2001) What's the Matter in Internet? University of Minnesota Press.

Rankin, M. B. (1993) Some Observations on Chinese Public Sphere. Modern China Vol. 19 (2) pp.158-182.

Scott, A. and Street, J. (2001) From Media Politics to e-Protest? The Use of Popular Culture and New Media in Parties and Social Movements. In Frank, W., ed., Culture and Politics in the Information Age. London and New York: Routledge, pp. 32-51.

Seaton, J. (1991) The Sociology of the Mass Media. In James C. and Jean S., eds. Power Without Responsibility: The Press and Broadcasting in Britain. London: Routledge, pp.249-276.

Sparks, C. (1998) Communism, Capitalism and the Mass Media. London: Sage.

Stevenson, N. (1995) Understanding Media Cultures: Social Theory and Mass 
Communication. London: Sage.

Thompson, J. B. (1990) Ideology and Modern Culture: Critical Social Theory in the Era of Mass Communication. Polity Press.

Thompson, J. B. (1995) The Media and Modernity: A Social Theory of the Media. Cambridge: Polity.

Tsui, L. (2005) Introduction: the Sociopolitical Internet in China. China Information Vol. 19 (2), pp.181-188.

Wakeman, F, JR. (1993) The Civil Society and Public Sphere Debate: Western Reflections on Chinese Political Culture. Modern China Vol. 19 (2), pp. 108-138.

Wall, M. A. (2003) Social Movements and the Net: Activist Journalism Goes Digital. In Kevin K., ed. Digital Journalism: Emerging Media and Changing Horizons of Journalism. Oxford: Rowman \& Littlefield Pubishers, Inc., pp.113-122.

Wang, X. F. (24 October 2006) Boke Shimingzhing de Beilun (Preposterous: Real-Name-Registration Policy in China). In Bu Xu Lianxiang (No Imagination) [online]. Available from http://www.wangxiaofeng.net/?p=491 [accessed 28 June 2008].

Wang, X. F. (16 January 2008) E Gao (Satire). In Bu Xu Lianxiang (No Imagination) [online]. Available from http://www.wangxiaofeng.net/?m=200801\&paged=2 [accessed 28 June 2008].

Winfield, B. H. and Peng Z. J. (2005) Chinese Media in Transition: Market or Party Controls? International Communication Gazette, Vol. 67(3), pp.255-270.

Williams, R. (1991) Base and Superstructure in Marxist Cultural Theory. In Chandra M. and Michael S., eds. Rethinking Popular Culture: Contemporary Perspectives in Cultural Studies. Berkeley, Los Angeles and Oxford: University of California Press, pp. 407-423.

Xiao, Y. (3 December 2004) Caifang Muzimei (Interview Muzimei) [Online]. Available from http://www.dw-world.de/dw/article/0,2144,1415268,00.html [accessed 19 November 2008].

Xin, H. (2002) The Surfer-in-Chief and the Would-be Kings of Content: A Short Study of Sina.com and Netease.com. In Stephanie H. D, Michael K and Ying H., eds. Media in China: Consumption, Content and Crisis. Routledge-Curzon, pp.192-199.

Xinkuaibao (11 November 2003) The Muzimei Phenomenon [online]. Available from http://news.sohu.com/86/01/news215430186.shtml [accessed 28 June 2008].

Yang, G. B. and Calhoun, C. (2007) Media, Society and the Rise of a Green Public Sphere in China. China Information Vol. 21(2), pp. 211-236.

Yang, M. M-H. (1997) Mass Media and Transnational Subjectivity in Shanghai: Notes 
on (Re)Cosmopolitanism in a Chinese Metropolis. In Aihwa O. and Donald D., eds. Ungrounded Empires: the Cultural Politics of Modern Chinese Transnationalism. New York: Routledge, pp. 287-322.

Zhang, L. L. (2006) Behind the 'Great Firewall': Decoding China's Internet Media Policies from the inside. Convergence Vol. 12 (3), pp. 271-291.

Zhang, W. (1997) Politics and Freedom of the Press. Australian Centre for Independent Journalism. Sydney: University of Technology.

Zhao, L. (31 October 2006) The Real Name Registration System [online]. Available from http://zonaeuropa.com/20061106_1.htm [accessed 28 June 2008].

Zheng, Y. N. and Wu, G. G (2005) Information Technology, Public Space, and Collective Action in China. Comparative Political Studies Vol. 38 (5), pp: 507-536.

Zhou, X. (11 November 2003) Nv Xieshou Yong Shenti Xiezuo: Muzimei Xingai Riji (A Female Writer Describes her Body: Muzimei's Sexual Diary) [online]. Available from http://news.sina.com.cn/s/2003-11-11/02312109068.shtml [accessed 28 June 2008]. 